\title{
Gambaran profil lipid pada pasien stroke iskemik dan stroke hemoragik yang di rawat inap di Irina F RSUP Prof. Dr. R. D. Kandou Manado periode Juli 2015-Juni 2016
}

\author{
${ }^{1}$ Astrid Laulo \\ ${ }^{2}$ Melke J. Tumboimbela \\ ${ }^{2}$ Corry N. Mahama
}

\author{
${ }^{1}$ Kandidat Skripsi Fakultas Kedokteran Universitas Sam Ratulangi Manado \\ ${ }^{2}$ Bagian Neurologi Fakultas Kedokteran Universitas Sam Ratulangi Manado \\ Email: astridlaulo@y7mail.com
}

\begin{abstract}
Stroke is rapidly developing clinical signs of focal or global disturbance of cerebral function, with symptoms lasting for 24 hours or longer or leads to death, with no apparent cause other than of vascular origin. This study was aimed to know description of lipid profile in patients with ischemic and haemorrhagic stroke hospitalized at Prof.Dr.R.D.Kandou hospital period of July 2015 - June 2016. This research was a descriptive retrospective research using secondary data, including the ischemic and haemorrhagic stroke patient's medical record. The results showed the highest percentage ischemic and haemorrhagic stroke patients is male, 51-60 year age group, who work as housewifes (40\%), had an optimal total cholesterol level, desired levels of HDL cholesterol, a near optimal of LDL cholesterol, an optimal triglyceride level. Based on this research, it can be concluded that patients with ischemic and hemorrhagic stroke had more patients with normal lipid levels.
\end{abstract}

Keywords: stroke, lipid profile

\begin{abstract}
Abstrak: Stroke adalah manifestasi klinik dari gangguan fungsi serebral, baik fokal maupun global, yang berlangsung dengan cepat, berlangsung lebih dari $24 \mathrm{jam}$, atau berakhir dengan kematian, tanpa ditemukannya penyebab selain gangguan vaskuler. Penelitian ini bertujuan untuk mengetahui gambaran profil lipid pada pasien stroke iskemik dan stroke hemoragik yang di rawat inap di RSUP Prof.Dr.R.D.Kandou Manado periode juli 2015-juni 2016. Metode yang digunakan bersifat deskriptif retrospektif yaitu dengan mengambil data sekunder penderita stroke iskemik dan stroke hemorgik periode juli 2015-juni 2016 di bagian rekam medik RSUP Prof.Dr.R.D.Kandou Manado. Hasil penelitian menunjukan bahwa persentase terbanyak pasien stroke iskemik dan stroke hemoragik adalah berjenis kelamin laki-laki, berusia 51-60 thn, bekerja sebagai ibu rumah tangga, memiliki kadar kolesterol total optimal, kadar kolesterol HDL diinginkan, kadar kolesterol LDL mendekati optimal, kadar trigliserida optimal. Berdasarkan hasil penilitian ini disimpulkan bahwa pasien stroke iskemik dan stroke hemoragik lebih banyak memiliki kadar profil lipid yang normal.
\end{abstract}

Kata kunci: stroke, profil lipid

Stroke menurut World Health Organization (WHO) adalah manifestasi klinis dari gangguan fungsi serebral, baik fokal maupun menyeluruh (global), yang berlangsung dengan cepat, dengan gejala yang berlangsung lebih dari 24 jam, dan dapat menyebabkan kematian, tanpa ditemukannya penyebab selain gangguan vaskuler. ${ }^{1}$ Di Indonesia, hasil Riskesdas tahun 2013 menunjukkan bahwa prevalensi stroke adalah 12/1000 penduduk dan prevalensi tertinggi di Sulawesi Selatan. ${ }^{2}$ 
Stroke dibagi menjadi dua yaitu stroke iskemik dan stroke hemoragik. Dari seluruh kejadian stroke, 1/3 adalah stroke hemoragik dan $2 / 3$ adalah stroke iskemik. ${ }^{3}$ Salah satu faktor resiko stroke yang dapat dimodifikasi adalah dislipidemia. Dislipidemia adalah jumlah lipid yang abnormal di dalam darah, seperti adanya peningkatan kadar kolesterol total, peningkatan trigliserida ataupun penurunan kadar High Density Lipoprotein (HDL. ${ }^{4}$ Kadar kolesterol yang tinggi dapat menyebabkan terjadinya aterosklerosis, yang berperan dalam terjadinya stroke iskemik. ${ }^{5}$ Peningkatan kadar kolesterol total sebesar $1 \mathrm{mmol} / \mathrm{L}$ dapat meningkatkan resiko terjadinya stroke iskemik sebesar $25 \% .^{6}$ Kadar kolesterol yang rendah akan menyebabkan endotel serebrovaskuler menjadi rapuh sehingga lebih rentan terhadap terjadinya mikroaneurisma yang merupakan temuan patologis utama pada Perdarahan Intraserebral ( $\mathrm{ICH})$ yang merupakan salah satu penyebab terjadinya stroke hemoragik. $^{7}$

Berdasarkan uraian diatas, peneliti merasa tertarik untuk melakukan penelitian tentang profil lipid pada pasien stroke iskemik dan stroke hemoragik yang di rawat inap di irina F RSUP Prof . Dr. R.D. Kandou Manado periode Juli 2015 hingga Juni 2016.

\section{METODE PENELITIAN}

Jenis penelitian ini ialah deskriptif retrospektif, yaitu dengan mengambil data sekunder berupa rekam medik pasien stroke iskemik dan stroke hemoragik di bagian Rekam Medik BLU RSUP Prof. Dr. R. D. Kandou Manado periode Juli 2015- Juni 2016. Populasi dari penelitian ini adalah semua pasien stroke yang di rawat inap di Irina F RSUP Prof. Dr. R. D. Kandou Manado periode juli 2015-juni 2016 yang, meliputi: biodata pasien (nama, umur, jenis kelamin), status kesehatan pasien (terkontrol atau didiagnosis oleh dokter spesialis saraf sebagai stroke berdasarkan riwayat penyakit, pemeriksaan neurologi dan pemeriksaan penunjang yang tercatat dalam rekam medik. Sampel penelitian ini ialah pasien yang telah didiagnosa stroke yang dirawat inap di Irina F RSUP Prof. DR. R. D. Kandou Manado periode Juli 2015-Juni 2016 dan memenuhi kriteria inklusi yaitu pasien yang di rawat inap di Irina F RSUP Prof. Dr. R. D. Kandou Manado periode Juli 2015 - Juni 2016 yang didiagnosis stroke oleh dokter spesialis saraf dan memiliki hasil pemeriksaan profil lipid yaitu HDL, LDL, Trigliserida dan Kolesterol Total dalam catatan rekam medik. Variabel penelitian ini terdiri dari jenis kelamin, usia, pekerjaan dan profil lipid yang meliputi HDL, LDL, Trigliserida dan Kolesterol Total.

\section{HASIL PENELITIAN}

Berdasarkan hasil penelitian yang dilakukan terhadap pasien stroke iskemik dan stroke hemoragik yang di rawat inap di Irina F RSUP Prof. Dr. R. D. Kandou Manado periode Juli 2015 - Juni 2016 diperoleh data yang disajikan dalam bentuk tabel distribusi frekuensi.

Distribusi pasien stroke iskemik dan stroke hemoragik yang terbanyak berdasarkan jenis kelamin ialah laki-laki yaitu 78 pasien $(36,80 \%)$ stroke iskemik dan 39 pasien $(18,40 \%)$ stroke hemoragik (Tabel 1).

Tabel 1. Distribusi pasien stroke berdasarkan jenis kelamin

\begin{tabular}{lcccc}
\hline \multirow{2}{*}{$\begin{array}{l}\text { Jenis } \\
\text { Kelamin }\end{array}$} & \multicolumn{2}{c}{$\begin{array}{c}\text { Stroke } \\
\text { Iskemik }\end{array}$} & \multicolumn{2}{c}{$\begin{array}{c}\text { Stroke } \\
\text { Hemoragik }\end{array}$} \\
\cline { 2 - 5 } & $\mathrm{N}$ & $\%$ & $\mathrm{~N}$ & $\%$ \\
\hline Laki-laki & 78 & 36,80 & 39 & 18,40 \\
Perempuan & 58 & 27,35 & 37 & 17,45 \\
Jumlah & 136 & 64,15 & 76 & 35,85 \\
\hline
\end{tabular}

Distribusi pasien stroke iskemik dan stroke hemoragik berdasarkan usia yang terbanyak ialah kelompok usia 51-60 thn dengan jumlah masing-masing 46 pasien $(21,7 \%)$ stroke iskemik dan 22 pasien $(10,38 \%)$ stroke hemoragik (Tabel 2).

Distribusi pasien stroke iskemik dan stroke hemoragik berdasarkan pekerjaan yang terbanyak adalah ibu rumah tangga (IRT) yaitu 41 pasien $(19,33 \%)$ stroke 
iskemik dan 24 pasien $(11,32 \%)$ stroke hemoragik (Tabel 3).

Tabel 2. Distribusi pasien stroke berdasarkan usia

\begin{tabular}{lcccc}
\hline \multirow{2}{*}{ Usia } & \multicolumn{2}{c}{$\begin{array}{c}\text { Stroke } \\
\text { Iskemik }\end{array}$} & \multicolumn{2}{c}{$\begin{array}{c}\text { Stroke } \\
\text { Hemoragik }\end{array}$} \\
\cline { 2 - 5 } & $\mathrm{N}$ & $\%$ & $\mathrm{~N}$ & $\%$ \\
\hline$<45$ thn & 15 & 7,07 & 11 & 5,19 \\
$45-50$ thn & 16 & 7,55 & 16 & 7,55 \\
$51-60$ thn & 46 & 21,7 & 22 & 10,38 \\
61-70 thn & 37 & 17,45 & 15 & 7,07 \\
$>70$ thn & 22 & 10,38 & 12 & 5,66 \\
Jumlah & 136 & 64,15 & 76 & 35,85 \\
\hline
\end{tabular}

Tabel 3. Distribusi pasien stroke berdasarkan pekerjaan

\begin{tabular}{lcccc}
\hline \multirow{2}{*}{ Pekerjaan } & \multicolumn{2}{c}{$\begin{array}{c}\text { Stroke } \\
\text { Iskemik }\end{array}$} & \multicolumn{2}{c}{$\begin{array}{c}\text { Stroke } \\
\text { Hemoragik }\end{array}$} \\
\cline { 2 - 5 } & $\mathrm{N}$ & $\%$ & $\mathrm{~N}$ & $\%$ \\
\hline Pelajar & 0 & 0 & 1 & 0,47 \\
PNS & 13 & 6,13 & 9 & 4,24 \\
Pegawai & 15 & 7,07 & 6 & 2,83 \\
Swasta & & & & \\
Wiraswasta & 13 & 6,13 & 2 & 0,94 \\
Pensiunan & 15 & 7,07 & 8 & 3,8 \\
IRT & 41 & 19,33 & 24 & 11,32 \\
Petani & 22 & 10,4 & 12 & 5,66 \\
Nelayan & 2 & 0,94 & 3 & 1,41 \\
Sopir & 2 & 0,94 & 5 & 2,35 \\
Tukang & 1 & 0,47 & 0 & 0 \\
Pekerja & 4 & 1,9 & 0 & 0 \\
Lepas & & & & \\
Tidak & 8 & 3,77 & 6 & 2,83 \\
Bekerja & & & & \\
Jumlah & 136 & 64,15 & 76 & 35,85 \\
\hline
\end{tabular}

Berdasarkan data pada Tabel 4 dapat dilihat bahwa kadar kolesterol total optimal adalah yang terbanyak pada pasien stroke iskemik dan stroke hemoragik yaitu 83 pasien $(39,15 \%)$ stroke iskemik dan 39 pasien $(18,4 \%)$ stroke hemoragik.

Berdasarkan data pada Tabel 5 dapat dilihat bahwa kadar kolesterol HDL yang terbanyak pada pasien stroke iskemik ialah kadar HDL rendah yaitu 69 pasien $(32,55 \%)$ sedangkan untuk stroke hemoragik kadar kolesterol HDL terbanyak ialah kolesterol HDL diinginkan yaitu 31 pasien $(14,62 \%)$.

Tabel 4. Distribusi pasien stroke berdasarkan kadar kolesterol total

\begin{tabular}{lcccc}
\hline \multirow{2}{*}{$\begin{array}{l}\text { Kadar } \\
\text { Kolesterol }\end{array}$} & \multicolumn{2}{c}{$\begin{array}{c}\text { Stroke } \\
\text { Iskemik }\end{array}$} & \multicolumn{2}{c}{$\begin{array}{c}\text { Stroke } \\
\text { Hemoragik }\end{array}$} \\
\cline { 2 - 5 } Total & $\mathrm{N}$ & $\%$ & $\mathrm{~N}$ & $\%$ \\
\hline Optimal & 83 & 39,15 & 39 & 18,4 \\
Diinginkan & 34 & 16,04 & 26 & 12,26 \\
Tinggi & 19 & 8,96 & 11 & 5,19 \\
Total & 136 & 64,15 & 76 & 35,85 \\
\hline
\end{tabular}

Tabel 5. Distribusi pasien stroke berdasarkan kadar kolesterol HDL

\begin{tabular}{|c|c|c|c|c|}
\hline \multirow{2}{*}{$\begin{array}{l}\text { Kadar } \\
\text { Kolesterol } \\
\text { HDL }\end{array}$} & \multicolumn{2}{|c|}{$\begin{array}{c}\text { Stroke } \\
\text { Iskemik }\end{array}$} & \multicolumn{2}{|c|}{$\begin{array}{c}\text { Stroke } \\
\text { Hemoragik }\end{array}$} \\
\hline & $\mathrm{N}$ & $\%$ & $\mathrm{~N}$ & $\%$ \\
\hline Rendah & 63 & & 28 & \\
\hline & 54 & 25 , & 1 & 14,62 \\
\hline & 13 & 6 & 17 & 8,02 \\
\hline Total & 136 & 64,15 & 76 & 35,85 \\
\hline
\end{tabular}

Berdasarkan data pada Tabel 6 dapat dilihat bahwa kadar kolesterol LDL mendekati optimal yang terbanyak pada pasien stroke iskemik dan stroke hemoragik yaitu 45 pasien $(21,23 \%)$ stroke iskemik dan 26 pasien $(12,26 \%)$ stroke hemoragik.

Tabel 6. Distribusi pasien stroke berdasarkan kadar kolesterol LDL

\begin{tabular}{lcccc}
\hline \multirow{2}{*}{$\begin{array}{l}\text { Kadar } \\
\text { Lolesterol }\end{array}$} & \multicolumn{2}{c}{$\begin{array}{c}\text { Stroke } \\
\text { Iskemik }\end{array}$} & \multicolumn{2}{c}{$\begin{array}{c}\text { Stroke } \\
\text { Hemoragik }\end{array}$} \\
\cline { 2 - 5 } & $\mathrm{N}$ & $\%$ & $\mathrm{~N}$ & $\%$ \\
\hline Optimal & 42 & 19,81 & 14 & 6,60 \\
Mendekati & 45 & 21,23 & 26 & 12,26 \\
Optimal & & & & \\
Diinginkan & 24 & 11,32 & 20 & 9,43 \\
Tinggi & 13 & 6,13 & 12 & 5,66 \\
Sangat Tinggi & 12 & 5,66 & 4 & 1,9 \\
Total & 136 & 64,15 & 76 & 35,85 \\
\hline
\end{tabular}

Berdasarkan data pada Tabel 7 dapat dilihat bahwa kadar trigliserida optimal yang terbanyak pada pasien stroke iskemik dan stroke hemoragik yaitu 107 pasien $(50,47 \%)$ stroke iskemik dan 66 pasien $(31,13 \%)$ stroke hemoragik. 
Tabel 7. Distribusi pasien stroke berdasarkan kadar trigliserida

\begin{tabular}{lcccc}
\hline \multirow{2}{*}{$\begin{array}{l}\text { Kadar } \\
\text { Trigliserida }\end{array}$} & \multicolumn{2}{c}{$\begin{array}{c}\text { Stroke } \\
\text { Iskemik }\end{array}$} & \multicolumn{2}{c}{$\begin{array}{c}\text { Stroke } \\
\text { Hemoragik }\end{array}$} \\
\cline { 2 - 5 } & $\mathrm{N}$ & $\%$ & $\mathrm{~N}$ & $\%$ \\
\hline Optimal & 107 & 50,47 & 66 & 31,13 \\
Diinginkan & 19 & 8,96 & 9 & 4,25 \\
Tinggi & 10 & 4,72 & 1 & 0,47 \\
Sangat Tinggi & 0 & 0 & 0 & 0 \\
Total & 136 & 64,15 & 76 & 35,85 \\
\hline
\end{tabular}

\section{BAHASAN}

Berdasarkan pengumpulan data secara retrospektif pada pasien stroke iskemik dan stroke hemoragik di Bagian Rekam Medik BLU RSUP. Prof. DR. R. D. Kandou Manado periode Juli 2015 - Juni 2016 maka didapatkan jumlah pasien stroke sebanyak 725 pasien namun data rekam medik pasien yang didapat dibagian Rekam Medik haya 302. Dari 302 pasien, ada 212 pasien yang masuk dalam kriteria inklusi yang terdiri dari 136 pasien stroke iskemik dan 76 pasien stroke hemoragik.

Berdasarkan hasil penelitian yang dilakukan menurut jenis kelamin pasien, didapatkan bahwa yang berjenis kelamin laki-laki merupakan kasus yang paling banyak terjadi yaitu sebanyak 116 pasien $(54,72 \%), \quad 78$ pasien $(36,80 \%)$ stroke iskemik dan 39 pasien $(18,40 \%)$ stroke hemoragik. Untuk pasien yang berjenis kelamin perempuan berjumlah 96 pasien $(45,28 \%), 58$ pasien $(27,35 \%)$ stroke iskemik dan 37 pasien $(17,45 \%)$ stroke hemoragik. Hasil penelitian ini sama dengan hasil penelitian Sherly F et al tahun 2014 dimana angka kejadian stroke pada perempuan lebih tinggi dibandingkan laki laki. ${ }^{8}$ Hal ini disebabkan karena perempuan lebih terlindungi dari penyakit jantung dan stroke sampai umur pertengahan akibat hormon estrogen yang dimilikinya. Akan tetapi pada penelitian ini didapatkan umur pasien berjenis kelamin perempuan diatas 50 tahun lebih banyak dari pasien perempuan usia pertengahan. Hal ini menunjukan bahwa setelah mengalami menopouse risiko perempuan sama dengan laki-laki untuk terkena serangan stroke. ${ }^{9}$

Berdasarkan data yang terkumpul, didapatkan bahwa distribusi usia pasien stroke terbanyak adalah kelompok usia 51 - 60 tahun sebanyak 68 pasien $(32,08 \%)$, 46 pasien $(21,7 \%)$ stroke iskemik dan 22 pasien $(10,38 \%)$ stroke hemoragik. Hal ini sesuai dengan penelitian yang dilakukan oleh Christanto ${ }^{10}$ bahwa pasien stroke yang terbanyak adalah pada kelompok umur 5160 thn. Insiden stroke akan meningkat secara eksponensial menjadi dua hingga tiga kali lipat setiap dekade diatas usia 50 thn dan ada yang menyebutkan 1 dari 3 orang yang berusia diatas 60 thn akan menderita salah satu jenis stroke. ${ }^{1}$

Berdasarkan hasil penelitian, didapatkan bahwa pasien stroke terbanyak dengan profesi sebagai ibu rumah tangga (IRT) yaitu 65 pasien $(30,65 \%)$ yang terdiri dari 41 pasien $(19,33 \%)$ stroke iskemik dan 24 pasien $(11,32 \%)$ stroke hemoragik. Hal ini sesuai dengan hasil penelitian Basri et al (2014) yaitu sebagian besar pasien stroke memiliki pekerjaan sebagai ibu rumah tangga. ${ }^{11}$

Berdasarkan hasil penelitian, didapatkan bahwa pada pasien stroke iskemik 39, $15 \%$ (83 pasien) memiliki kadar kolesterol total yang optimal, terdapat 34 pasien $(16,04 \%)$ memiliki kadar yang diinginkan dan 19 pasien memiliki kadar kolesterol yang tinggi. Untuk stroke hemoragik, 39 pasien $(18,4 \%)$ memiliki kadar yang optimal, 26 pasien $(12,26 \%)$ yang diinginkan dan 11 pasien $(5,19 \%)$ memiliki kadar yang tinggi. Resiko terjadinya aterosklerosis dan penyakit arteri koroner atau penyakit arteri karotis meningkat pada seseorang yang memiliki kadar kolesterol total yang tinggi. Kadar kolesterol rendah biasanya lebih baik dibandingkan dengan kadar kolesterol yang tinggi, tetapi kadar yang terlalu rendah juga tidak baik. Kadar kolesterol yang tinggi mempromosikan pembentukan plak di arteri yang memasok jantung dan otak. ${ }^{12}$

Dari data pasien stroke berdasarkan kadar kolesterol HDL menunjukkan bahwa pada pasien stroke iskemik ada 69 pasien $(32,55 \%)$ memiliki kadar kolesterol HDL yang rendah, 54 pasien $(25,47 \%)$ normal, dan 13 pasien $(6,13 \%)$ tinggi. Untuk stroke 
hemoragik, 28 pasien $(13,21 \%)$ normal, 31 pasien $(14,62 \%)$ normal dan 17 pasien ( 8,02\%) memiliki kadar yang tinggi. Kadar HDL kolesterol rendah dapat meningkatkan risiko terjadinya pembekuan darah. Pembentukan bekuan darah dalam arteri karotis bisa menyebabkan resiko stroke. Kadar HDL kolesterol terlalu rendah sama bahayanya dengan memiliki kadar LDL kolesterol terlalu tinggi. Kadar HDL kolesterol yang terlalu rendah yang diiringi kadar LDL kolesterol yang tinggi dapat memicu pembentukan plak dalam pembuluh arteri, dan berpotensi menghambat aliran darah ke semua organ, dan otak. ${ }^{13}$

Dari data pasien stroke berdasarkan kadar kolesterol LDL menunjukkan bahwa pada pasien stroke iskemik ada 42 pasien $(19,81 \%)$ memiliki kadar kolesterol LDL yang optimal, 45 pasien $(21,23 \%)$ mendekati optimal, 24 pasien $(11,32 \%)$ yang diinginkan, 13 pasien $(6,13 \%)$ tinggi, dan 12 pasien $(5,66 \%)$ sangat tinggi tinggi. Untuk stroke hemoragik, ada 14 pasien $(6,60 \%)$ memiliki kadar kolesterol LDL yang optimal, 26 pasien $(12,26 \%)$ mendekati optimal, 20 pasien $(9,43 \%)$ yang diinginkan, 12 pasien $(5,66 \%)$ tinggi, dan 4 pasien $(1,9 \%)$ sangat tinggi. LDL kolesterol memiliki kecenderungan melekat di dinding pembuluh darah sehingga dapat menyempitkan pembuluh darah, terutama pembuluh darah kecil yang menyuplai makanan ke jantung dan otak. Kadar LDL kolesterol berlebihan akan mengendap pada dinding pembuluh darah arteri dan membentuk plak serta menimbulkan dan menyebabkan penumpukan lemak yang memicu aterosklerosis. Plak terlepas dan menyebabkan stroke. ${ }^{13}$

Berdasarkan hasil penelitian, didapatkan bahwa pada pasien stroke iskemik ada 107 pasien $(50,47 \%)$ memiliki kadar trigliserida yang optimal, ada 19 pasien $(8,96 \%)$ memiliki kadar yang diinginkan dan 10 pasien memiliki kadar trigliserida yang tinggi. Untuk stroke hemoragik, 66 pasien $(31,13 \%)$ yang optimal, 9 pasien $(4,25 \%)$ yang diinginkan dan 1 pasien $(0,47 \%)$ memiliki kadar yang tinggi. Tidak ditemukan pasien dengan kadar trigliserida yang sangat tinggi pada pasien stroke iskemik dan stroke hemoragik. Trigliserida menyusun sekitar 90\% lemak dalam makanan, tubuh membutuhkan trigliserida untuk energi, tetapi bila jumlahnya terlalu banyak akan buruk bagi pembuluh arteri. Kadar trigliserida darah diatas $250 \mathrm{mg} / \mathrm{dL}$ dianggap abnormal, tetapi kadar yang tinggi ini tidak selalu meningkatkan resiko terjadinya aterosklerosis maupun penyakit arteri koroner. $^{13}$

Berdasarkan hasil penelitian ini didapatkan bahwa profil lipid lebih berpengaruh terhadap kejadian stroke iskemik daripada stroke hemoragik. Kadar Kolesterol Total, Kolesterol HDL, kolesterol LDL dan Trigliserida pada penelitian ini masih lebih banyak dalam batas normal atau yang diinginkan. Hal ini juga sesuai dengan penelitian yang dilakukan oleh Chaudry et al (2014) di India bahwa kadar profil lipid pada pasien stroke iskemik dan stroke hemoragik dalam batas normal atau yang diinginkan lebih banyak didapatkan dan mereka juga menjelaskan bahwa terdapat hubungan yang positif antara kadar kolestrol dengan stroke iskemik tapi tidak dengan stroke hemoragik. ${ }^{14}$

\section{SIMPULAN}

Berdasarkan hasil penelitian pada pasien stroke iskemik dan stroke hemoragik di Bagian Rekam Medik BLU RSUP. Prof. DR. R. D. Kandou Manado periode Juli 2015-Juni 2016 dapat disimpulkan bahwa mayoritas kasus ialah pasien stroke iskemik, jenis kelamin laki-laki, kelompok usia 51-60 tahun. IRT merupakan pekerjaan terbanyak pada pasien stroke.

Kadar Kolesterol Total, Kolesterol HDL, kolesterol LDL dan Trigliserida pada penelitian ini masih lebih banyak dalam batas normal atau yang diinginkan. Profil lipid abnormal lebih banyak dijumpai pada stroke iskemik daripada stroke hemoragik

\section{DAFTAR PUSTAKA}

1. Tammasse J. Stroke dan pencegahannya. 
Makassar: Identitas Universitas Hasanuddin; 2013. h. 6-97

2. Badan Penelitian dan Pengembangan Kesehatan Kementerian Kesehatan RI. Penyajian Pokok-Pokok Hasil Riset Kesehatan Dasar 2013. Jakarta: Departemen Kesehatan republik Indonesia; 2014

3. Sacco R, Kosner S, Broderick J, Caplan L, Cannor, Culebras A, et al. An Updated Definition of Stroke for the 21st Century. American Heart Association/American Stroke Association. July 2013; 44: 2064-89

4. Khan MN, Khan HD, Ahmad M, Umar M. 2014. Serum Total and HDLCholesterol in Ischemic and Hemorrhagic Stroke. Ann.Pak.Inst.Med. Sci.10(1): 22-6.

5. Sudoyo AW, Setiyohadi B, Alwi I, Simadibrata M, Setiati S. 2007. Buku Ajar Ilmu Penyakit Dalam. Jakarta: Pusat Penerbitan Departemen Ilmu Penyakit Dalam FKUI pp.1926-33

6. Baluch UT, Kiani I, Nisa ZU, Badshah M. Association of Dyslipidemia and Ischemic Stroke. Ann Pak Inst Med Sci. 2008. 4(3):165-7

7. Wang X, Dong Y, Qi X, Huang C, Hou L. 2013. Cholesterol Levels and Risk of Hemorrhagic Stroke. Stroke. 10:1833-9

8. Fandri S, Utomo W, Dewi PA. Perbedaan status fungsional pasien stroke saat masuk dan keluar ruang rawat inap
RSUD Arifin Achmad. JOM PSIK. 2014;1:2

9. Heart And Stroke Foundation. A Perfect Strorm Of Heart Disease Looming On Our Horizon. [cited 20 desember 2012]. Available from: http://heartandstroke. Com

10.Christanto R, Mahama CN, Tumboimbela MJ. Profil FaktorFaktor Resiko Pada Pasien Stroke Yang Dirawat Inap di Irina $F$ Neurologi RSUP Prof. Dr. R. D. Kandou Manado Periode Januari-Oktober 2012. Jurnal e-Clinic. November 2014

11.Basri M, Yusdar. Hubungan golongan darah dengan prevalensi stroke di rumah sakit khusus daerah provinsi Sulawesi Utara. Kesehatan dagnosis. 2014:4:642

12. Caplan LR. Stroke. Chapter 4 How Can Stroke Be Prevented. American Academy of Neurology. New York : 2006. p.39-56

13.Vansa TE. Hubungan Profil Lipid Darah Pada Penderita Stroke Iskemik. Semarang: Fakultas Kedokteran Universitas Muhammadiyah Semarang; 2013

14. Chaudhury SR, Ghosh S, Kar D. Comparative Lipid Profile Study Between Ischemic and Hemorrhagic Stroke. J Chem Pharm Res. 2014;6(11):20-27 